\title{
Project-based learning usage in $L 2$ teaching in a contemporary comprehensive school (on the example of English as a foreign language classroom)
}

\section{Uso da aprendizagem baseada em projeto no ensino L2 em uma escola abrangente contemporânea (no exemplo da sala de aula de inglês como língua estrangeira)}

\section{Uso del aprendizaje basado en proyectos en la enseñanza L2 en una escuela integral contemporánea (en el ejemplo del aula de inglés como lengua extranjera)}

\author{
Alla Guslyakova1 (iD, Nina Guslyakova² (iD), Nailya Valeeva³ (iD), Ludmila Veretennikova4 (i) \\ ${ }^{1}$ Peoples' Friendship University of Russia (RUDN University), Moscow, Russia; Moscow State Pedagogical University, \\ Moscow, Russia. \\ 2 South Ural State Humanitarian Pedagogical University, Chelyabinsk, Russia. \\ ${ }^{3}$ Peoples' Friendship University of Russia (RUDN University), Moscow, Russia. \\ ${ }^{4}$ Moscow State Pedagogical University, Moscow, Russia. \\ Corresponding author: \\ Alla Guslyakova \\ Email: aguslyakova@bk.ru
}

How to cite: Guslyakova, A., Guslyakova, N., Valeeva, N., \& Veretennikova, L. (2021). Project-based learning usage in L2 teaching in a contemporary comprehensive school (on the example of English as a foreign language classroom). Revista Tempos e Espaços em Educação, 14(33), e16754. http://dx.doi.org/10.20952/revtee.v14i33.16754

\begin{abstract}
The article covers the problem of project-based learning (PBL) in present-day foreign language classes. The main aim of this research is to identify how PBL method can be implemented in teaching a foreign language (for example, English as a second language) in a modern comprehensive school and to give recommendations on organizing a foreign language class with the help of PBL. The working hypothesis of the study says that PBL method can be a relevant and effective methodological technique allowing educators to improve the quality of school education and motivating young learners to work hard at $\mathrm{L} 2$ classes and study a foreign language better. For the effective analysis and estimation of project-based learning in teaching ESL a two-step experiment was conducted. Overall, the results of the study demonstrated the importance of introduction of project-based learning in foreign language classes as an essential component of the teacher's work in the present-day education. They also proved that project-based learning should be a must in
\end{abstract}


every educator's pedagogical "piggy-bank" because PBL is an effective professional instrument which may overcome the latest demands and challenges of the third millennium society.

Keywords: Project-based learning (PBL). The English language. ESL lesson. A teacher. Learners. A survey. Motivation. Creativity.

\section{RESUMO}

$\mathrm{O}$ artigo aborda o problema da aprendizagem baseada em projetos (PBL) nas aulas de línguas estrangeiras atuais. O objetivo principal desta pesquisa é identificar como o método PBL pode ser implementado no ensino de uma língua estrangeira (por exemplo, Inglês como segunda língua) em uma escola abrangente moderna e dar recomendações sobre a organização de uma aula de língua estrangeira com a ajuda do PBL. A hipótese de trabalho do estudo afirma que o método PBL pode ser uma técnica metodológica relevante e eficaz que permite aos educadores melhorar a qualidade da educação escolar e motivar os jovens alunos a trabalharem nas aulas de L2 e a estudar melhor uma língua estrangeira. Para a análise e estimativa eficazes da aprendizagem baseada em projetos no ensino de ESL, foi conduzido um experimento em duas etapas. No geral, os resultados do estudo demonstraram a importância da introdução da aprendizagem baseada em projetos nas aulas de línguas estrangeiras como um componente essencial do trabalho do professor na educação atual. Eles também provaram que a aprendizagem baseada em projetos deve ser uma obrigação no "cofrinho" pedagógico de todo educador, porque o PBL é um instrumento profissional eficaz que pode superar as últimas demandas e desafios da sociedade do terceiro milênio.

Palavras-chave: Aprendizagem baseada em projetos (PBL). A língua inglesa. Lição de ESL. Um professor. Aprendizes. Um questionário. Motivação. Criatividade.

\section{RESUMEN}

El artículo aborda el problema del aprendizaje basado en proyectos (ABP) en las clases de lenguas extranjeras actuales. El objetivo principal de esta investigación es identificar cómo se puede implementar el método PBL en la enseñanza de una lengua extranjera (por ejemplo, inglés como segundo idioma) en una escuela integral moderna y dar recomendaciones sobre cómo organizar una clase de lengua extranjera con la ayuda de PBL. La hipótesis de trabajo del estudio dice que el método ABP puede ser una técnica metodológica relevante y efectiva que permita a los educadores mejorar la calidad de la educación escolar y motivar a los jóvenes estudiantes a trabajar duro en las clases de L2 y estudiar mejor una lengua extranjera. Para el análisis y la estimación efectivos del aprendizaje basado en proyectos en la enseñanza del inglés como segundo idioma, se llevó a cabo un experimento de dos pasos. En general, los resultados del estudio demostraron la importancia de la introducción del aprendizaje basado en proyectos en las clases de lenguas extranjeras como un componente esencial del trabajo del maestro en la educación actual. También demostraron que el aprendizaje basado en proyectos debería ser una necesidad en la "alcancía" pedagógica de todo educador porque el $A B P$ es un instrumento profesional eficaz que puede superar las últimas demandas y desafíos de la sociedad del tercer milenio.

Palabras clave: Aprendizaje basado en proyectos (ABP). El idioma Ingles. Lección de ESL. Un profesor. Aprendices. Una encuesta. Motivación. Creatividad.

\section{INTRODUCTION}

At present, modern teachers, tutors and methodologists tend to introduce different innovative approaches into the lessons of school curriculum subjects and in particular into foreign languages (for example, English) by adding methodological developments and experience of the past and present pedagogics of Russian Federation and other countries. One of the most popular, effective and efficient approaches to master a foreign language at a modern school education level can be described as project-based learning (or PBL) (Aplaeva, 2017; Poonpon, 2011; Thuan, 2018; 
Veretennikova, 2019). A great number of studies on PBL have been carried out on a global scale (Lam et. al., 2010), proving to characterize this particular methodology as one of the most highdemand phenomena in the 21st century education.

Project-based learning is defined as a model, a "purposeful activity" (Beckett, 2006; Muniandi, 2000; Wolk, 2004) that organizes learning in a meaningful context around different projects. It is a teaching method in which students gain knowledge and skills by working for an extended period of time to investigate and respond to an authentic, engaging and complex question, problem, or challenge and culminate in realistic products or presentations (Aplaeva, 2017). Thus, project-based learning is both a process- and product-orientated phenomenon (Stoller, 1997).

While focusing on project implementation, schoolchildren are involved in research, handson, creative, educational and cognitive activities, which can positively affect their motivational sphere. Moreover, in the process of working on projects, children collaborate in teams, which means effective development of personal communication skills. In addition, they are also immersed in a creative environment inspiring them to mobilize their individual's external and internal resources for the best creative problem-solving. Therefore, we may conclude that project-based learning is an opportunity to develop a child's creative and critical thinking as well as empower and challenge a young learner to raise their confidence, self-esteem and autonomy (Fried-Booth, 2002; Solomon, 2003; Srikrai, 2008; Willie, 2001).

PBL method being realized within the frameworks of foreign language (L2) teaching reveals essential principles of the humanistic approach (e.g. work, communication and cooperation with other learners, practical and tangible goals and results) in the present-day Pedagogics, laid down by such educators-innovators and humanists as V.A. Sukhomlinsky, V.F. Shatalov, Sh.A. Amonashvili and others.

As the main purpose of $L 2$ teaching involves shaping a pupil's communicative competence, their ability and willingness to carry out foreign language communication, to speak, listen and express thoughts while understanding others and being understood, the PBL method turns into an important instrument of a child's subject and metasubject knowledge and skills, including their foreign language competence.

Consequently, the purpose of our study is to identify the specifics of using PBL method in teaching foreign languages (based on the example of the English language) in a modern comprehensive school and developing methodological recommendations for organizing foreign language classes with the help of project-based learning.

We hypothesize that the PBL method is a relevant and effective methodological technique used by an educator in L2 classes, which can improve the quality of comprehensive school education and trigger pupils' motivation for their further language training.

Our study is also guided by the following three research questions.

1. What is the history of the development of PBL method in Russian and foreign pedagogical science?

2. How is PBL introduced in a contemporary comprehensive school at the level of teaching materials?

3. How do young learners respond to PBL foreign language classes and what issues should an L2 teacher pay attention to when planning a project-based learning classroom activity?.

\section{LITERATURE REVIEW}

Project-based learning method is a dynamic approach (Nguyen, 2011) which started from the ideas of Ancient Rome, the Age of Enlightenment and a philosophical movement of pragmatism that originated in the United States in the second half of the 19th century. Primarily, this method was widely implemented in science education (Kalvu, 2015). For example, a prominent American 
teacher and scholar David Snedden, who taught science in American agriculture classes in US schools, actively used PBL in his academic practice (Sadeghi et al., 2016).

Back in the Roman School of Arts, a "competition", named as a "project" (or a program or a plan), was introduced into the curriculum when educators and scholars allowed students to create sketches of various structures.

Since then, the competition has entered the general education system and has left three main features of the project: orientation towards knowledge acquisition in the process of project development; focus on realism and a specific object of activity that will be created in the process of project development.

Later on, at the Age of Enlightenment famous philosophers of the XVIIIth century (JeanJacques Rousseau and Johann Heinrich Pestalozzi) speculated on the essence of bringing students together to fulfill one common, exciting and perspective goal (Rousseau, 1981) and combining learning with work, and the need to make both processes diverse and interesting. Pestalozzi tested this approach on children from poor or unfavorable families (Pestalozzi, 1965).

In the XIXth century and at the beginning of the XXth one a new philosophical movement, pragmatism (J. Dewey, W. Kilpatrick, H. Gaudig, G. Kerschensteiner), appeared in the Western and American culture and continued promoting knowledge in the form of practical application in everyday life (Frey, 1986:31) The implementation of the project method was based on such pedagogical principles, expressed by many progressive educators (Chrysafidis, 2005) as:

a) promotion of manual activity instead of memorization and verbalism;

b) learners' active participation in the educative process;

c) exploitation of facts relating to the immediate reality as a source for instruction (Fragoulis, 2009).

In Russia, the development of project-based learning method began almost simultaneously with the United States and Europe. In 1905 S.T. Shatsky with a group of teachers began active usage of PBL in training (Shatskiy, 1965). The method was widely applied in practice by such educators as E.G. Kagarov (Kagarov, 1926), M.V. Krupenin, V.N. Shulgin and B.V. Ignatiev. After the Russian revolution in 1917, at the direction of Nadezhda Krupskaya (Krupskaya, 1962), it was popularized in many educational institutions and therefore, it is necessary to mention that the elements of the project-oriented technology were being actively implemented by such prominent Soviet educators as I.P. Ivanov, A.S. Makarenko and A.N. Lutoshkin.

In L2 teaching, the project-based learning approach became most relevant in the late 1980s of the XXth century. At this time, publishing European and American companies released methodological recommendations on the use of the project-based learning in teaching foreign languages.

In Russian Federation PBL began to be actively implemented during the approval of the Federal State Educational Standards, in its new meaning for Pedagogics, while maintaining its historical essence and goal - to stimulate learners' cognitive interest in certain problems, relying on the search for theoretical information, to bring and demonstrate knowledge in practice (Erokhina, 2018). According to Levine (Levine, 2004) students engage in purposeful communication to complete authentic activities - tasks with real world relevance and utility; they thus have the opportunity to use a foreign language in a relatively natural context and participate in meaningful activities which require authentic language use. Overall, project-based learning provides opportunities for the natural integration of all four language skills, that is reading, writing, listening and speaking. While working on a project a learner has a chance to "recycle known language and skills in a relatively natural context" (Haines, 1989, p.1). Besides, according to J. Simpson, while concentrating on certain project work it is essential to remember the following key features of PBL methodology within the frames of a foreign language training.

1. The de-emphasis of teacher-directed activities. 
2. A student-centered learning activity whereby students plan, complete and present the task.

3. Hands-on activities and the use of authentic resources and technologies.

4. Complex explorations over a period of time.

5. Challenging questions, problems or topics of learners' interest which become the center of the project and the training process.

6. A collaborative rather than a competitive learning environment; the use of a variety of skills such as social and management ones.

7. The use of effort in connecting ideas and acquiring new skills during different project stages.

8. The production of meaningful artifacts that can be shared with peers, teachers, and experts in a public presentation; an opportunity to share resources, ideas and expertise through the whole process in the classroom.

9. Assessment in both the process of working from the first stage to the last stage and the finished project (Simpson, 2011).

In summary, PBL is very beneficial to foreign language learners strategically and tactfully and the next question, which is raised here, in this research, is what should be done to maximize schoolchildren's benefits of project-based learning in a contemporary comprehensive school.

\section{MATERIALS AND METHODS}

To analyze and estimate how PBL method makes the difference when teaching English as a foreign language we conducted an experiment which consisted of two stages. The first stage focused on the analysis of the academic and methodological complex "Spotlight 10" by O.V. Afanasyeva, D. Dooley, I.V. Mikheeva, B. Obi, V. Evans aiming to teach English to pupils of the 10th grade of a comprehensive school.

Fig. 1. Academic and methodological complex "Spotlight 10" (Student's Book)

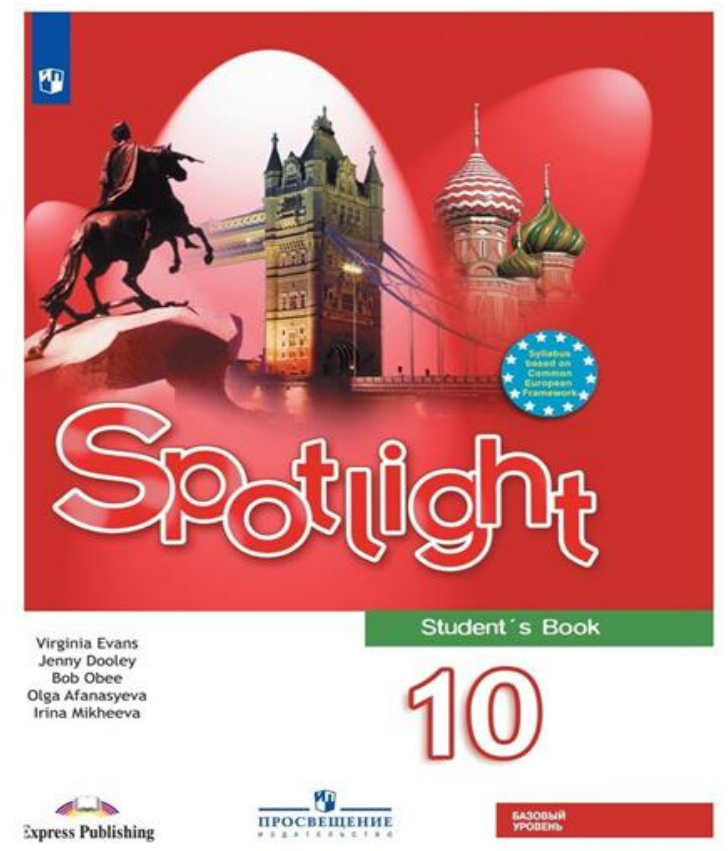

The scope of our interest was the presence of PBL tasks offered to learners in this ESL complex. 
The second stage of the experimental work involved the conduction of the PBL lesson in the 10th grade of the state budgetary educational institution of the city of Zelenograd (an administrative okrug of Moscow, Russia) in 2021. The key purpose of the experiment was to understand how the usage of PBL method influences schoolchildren's assimilation of knowledge by using "Spotlight 10" in the classroom. The study included 21 pupils aged 16 of the senior comprehensive school learning English as their second language. At the end of the experimental lesson a feedback survey was conducted to estimate the degree of satisfaction with a lesson using a project-based teaching method integrated in the tasks of "Spotlight 10".

The academic and methodological complex "Spotlight 10" has received positive feedbacks and reviews from the Russian Academy of Sciences (RAS) and the Russian Authors' Society (RAO) for compliance with the federal component of the State educational standard of secondary (complete) general education. "Spotlight 10" complex consists of a textbook (Student's book), a workbook for students (Workbook), a book for a teacher (Teacher's book), a book for reading (Reader), a manual for test tasks (Test Booklet) and a disc for listening (Audio). It also follows five basic didactic teaching principles (see figure 2 below).

Fig. 2. Five basic didactic teaching principles of "Spotlight 10" complex

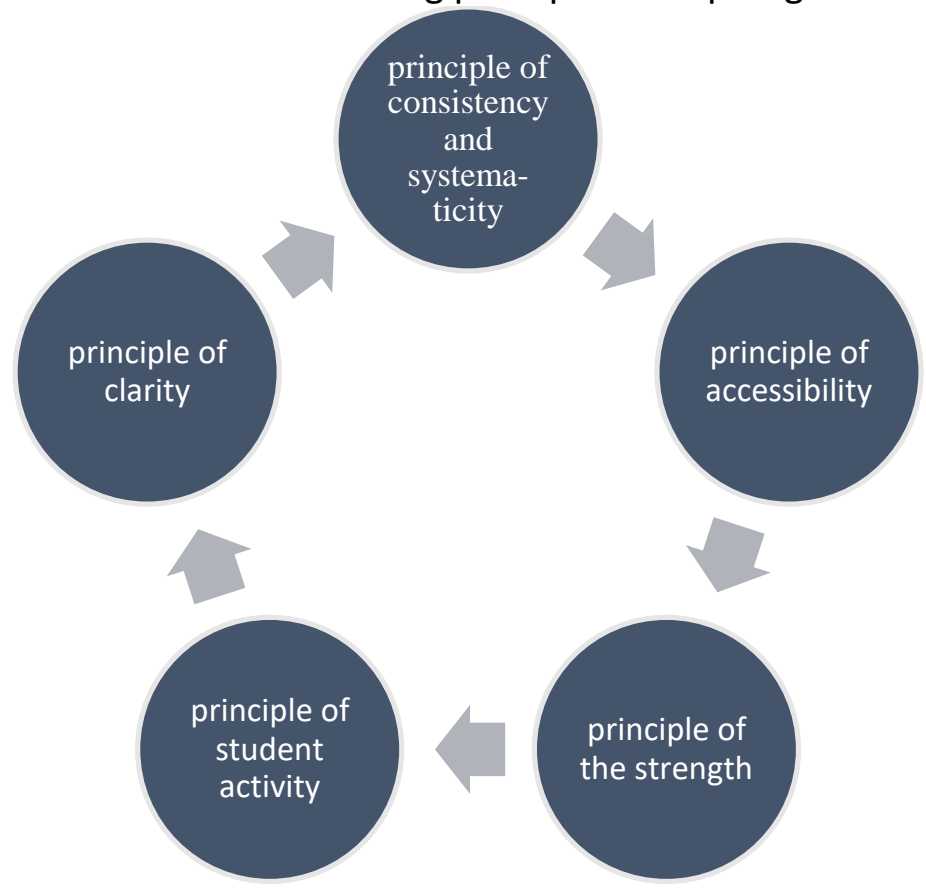

The first principle of consistency and systematicity means that all the information blocks containing lexical, grammatical and phonetic materials are divided into eight training modules. Training material of each module presented in the textbook correlates with the content of a workbook, where a learner can do additional assignments in each lesson on the topics given in the Student's textbook. The test booklet provides learners with an opportunity to check their language knowledge.

The second teaching principle (the principle of accessibility) follows the required degree of difficulty. The textbook contains special tasks for certain grammar rules and grammatical structures and categories. One can read the rules as well as complete tasks for each of them at the end of the textbook in the additional section "Grammar check" for each module.

The third principle of the strength of the assimilation of knowledge, abilities and skills in combination with creative activity help young learners to cement their knowledge gained in the lessons by means of its repetition in each subsequent lesson. There are creative tasks of a 
communicative character to practice and drill separate lexical and grammatical constructions or a certain type of vocabulary.

The fourth didactic principle of student activity demonstrates different types of communication between a teacher and a learner, between learners, work in groups and individual work. It is necessary to underline that the teacher is not the main dominant of students' activities.

And finally, the last (the fifth) principle of clarity and a variety of methods is used to increase the effectiveness of training. "Spotlight 10" complex contains multiple visual pictures, illustrations, graphs and tables to make the ESL learning process understandable, smooth, exciting and thoughtprovoking.

Therefore, the academic and methodological complex "Spotlight 10" can be characterized as a modern, progressive didactic platform for learning English as a foreign language at the senior stage of a comprehensive school which basic teaching principles may successfully realize a projectbased learning method. The tasks offered in "Spotlight 10" have proved this argument.

\section{FINDINGS}

"Spotlight 10" complex demonstrates various tasks where PBL method is implemented, aimed at communication, search and research.

For example:

Module 4, the topic is "Earth Alert!"; section 4a introduces the problem of environmental protection. The first PBL task motivates young learners to answer the following questions: "What should we do to protect the environment? Use the ideas listed to make sentences" (see figure 3).

Fig. 3. The example of "Spotlight 10" complex PBL task focused on the discussion of environmental issues among senior schoolchildren

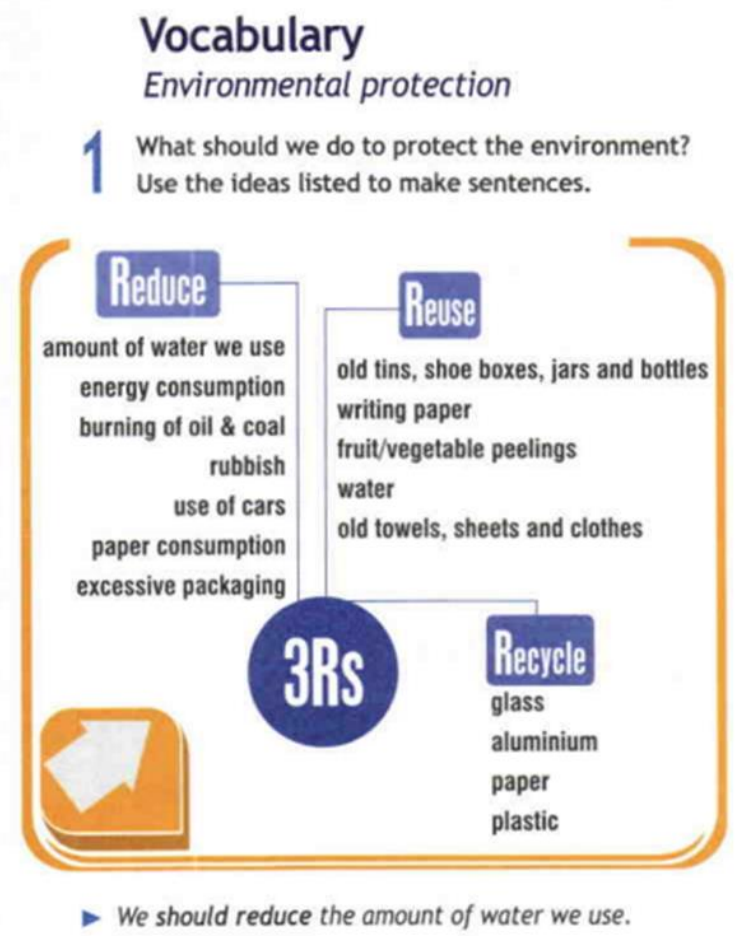

This PBL task shows that the learners operate with the material on the topic of "protecting the environment". The task can be effectively expanded, done in pairs or groups or individually while using resources for research. Learners are free to draw up infographics of environmental problems 
in Russian Federation (or in other states including English-speaking countries) and propose solutions to multiple ecological problems and challenges of the XXIst century.

Continuing this environmental topic, on the same page of "Spotlight 10" student's book, there is another PBL task (see figure 4 below).

Fig.4. The example of "Spotlight 10" complex PBL task aimed to motivate young learners' individual response to the environmental issues on the planet

\title{
Writing (a quiz)
}

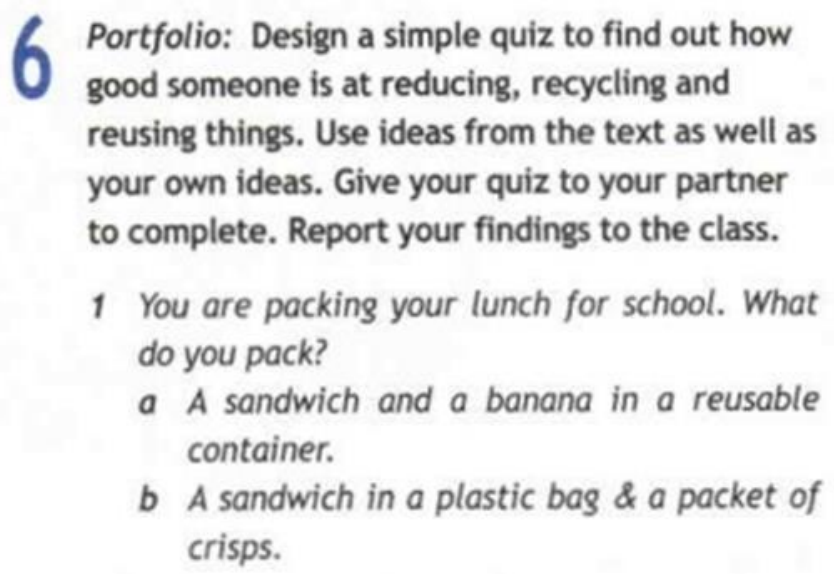

This assignment offers schoolchildren to create a small quiz on the topic, then work in pairs, run each other's tests and report to the whole class about their "eco" test findings. In this case, learners can use multiple Internet resources, online voting, video channels and prepare a specific product on a definite topic of their team or pair.

One more effective PBL task is introduced in a special "Culture corner" at the end of the module dedicated to the environmental issues (see figure 5).

Fig. 5. The example of "Spotlight 10" complex PBL task focused on the environmental problemsolving within a team

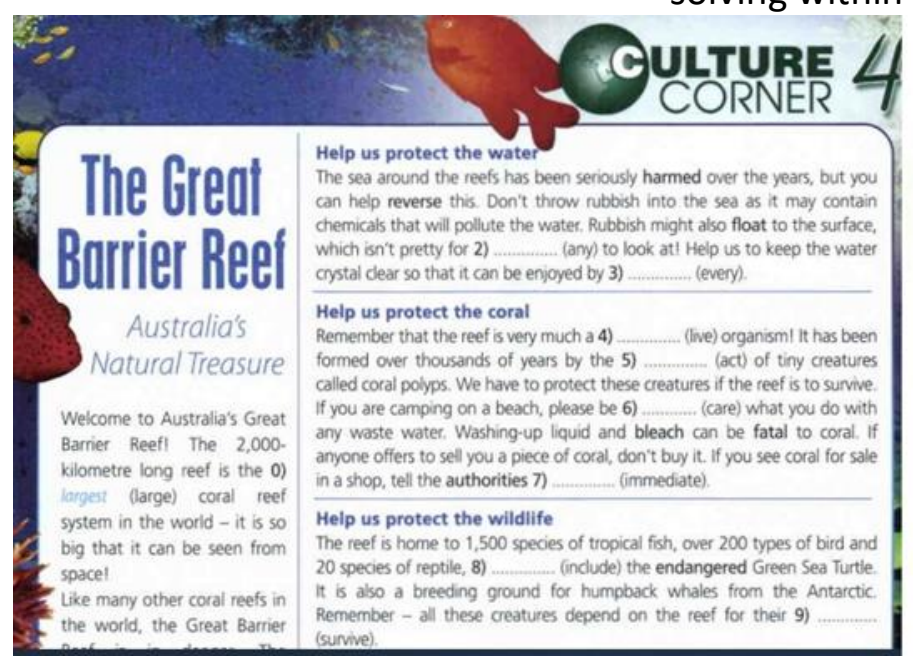

\section{Study skills}

\author{
Working in groups \\ When you work in groups, it is important to decide who will \\ perform what task. Assigning group roles according to each \\ person's character will help the group work better. \\ Portfolio: Work in groups. Think of a protected area in your \\ country. \\ - Where is it? - What lives there? \\ - What problems has it got? \\ - What can tourists do to help? \\ Collect information. Use your answers to prepare a short \\ article for the school magazine.
}

After reading the information about famous Australian barrier reefs, learners are offered to conduct research on protected areas in their own country. The learners have to work in groups where each participant is responsible for a particular task. Finally, each group makes a presentation about the location chosen and focus on the ecological policy and activities which take place there. 
To sum up, the analysis of the PBL tasks introduced in the academic and methodological complex "Spotlight 10" shows that contemporary EFL teaching materials (textbooks, workbooks, readers) contain various tasks related to the project methodology in the lesson. These tasks inclined to use the PBL method are aimed at improving learners' research skills, gradually forming their knowledge and developing all components of schoolchildren's communicative competence. Moreover, the PBL tasks take into account learners' age characteristics and the sphere of their interests ensuring the formation of readiness for self-development and continuous education.

In order to prove the positives of the PBL method application, an experimental lesson on the topic of "Spending money" was held in the 10th grade where the above-mentioned approach was used (see figure 6).

Fig. 6. The usage of PBL method in the task related to the problem of young learners' attitude towards money and finance issues (Spotlight 10)

PSHE ACROSS THE CURRICULUM

Personal, Social \& Health Education

\section{How responsible are you with your money?}

Money choices can be difficult. What would you do in the following situations?

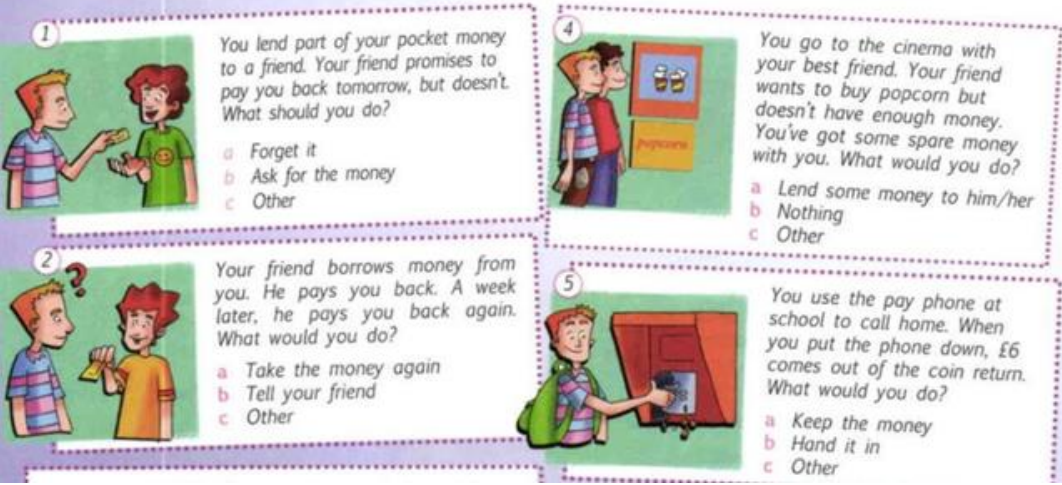

Prepare a survey with yes/no answers to find - out how responsible your class is with money. - You find a wallet in the street with an address in it. Do you keep the wallet? Yes/No Write a paragraph about your findings. Most of the class seem to be quite responsible with money. Almost everyone would ...

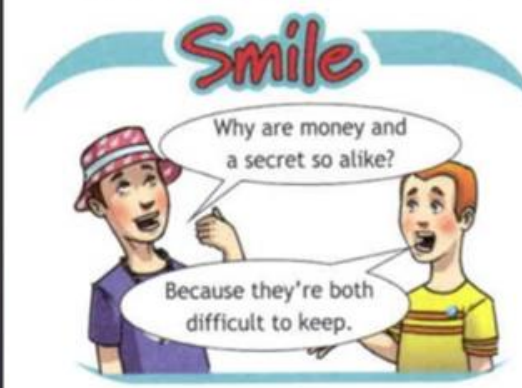

In our opinion, the purpose of using the method within the framework of this topic and, accordingly, the main purpose of the whole lesson was to improve the skills of monologue and dialogical speech based on the revision of the lexical material on the topic of the lesson and the one from the previous module, that is "Spending" and "Traveling". Thus, the following practical tasks were solved within the experimental lesson: the improvement of communicative skills (monologue and dialogue) and the ability to explain information in a foreign language (presentation of projects); vocabulary as well as grammar revision and repetition.

We were expecting the following young learners' estimated results.

1. On a personal level - being aware of financial resources; being able to rationally plan a budget and critically assess their actions and purchases.

2. On a subject level - assimilating the proper English language vocabulary (e.g. clothes and accessories, household bills, eating out, mobile phone cards, sweets and snacks, rent, bus fares, petrol, computer games, Cds \DVDs, going out (cinema, sporting events), magazines \books \ comics, supermarket shopping, budget, borrow, cash, coins, currency, lend, debt, invest, tips) and using it in oral and written speech.

3.On a metasubject level - being able to organize educational cooperation, express one's opinion, listen to the other learners' opinion, assess the degree of goal achievement, control the time, find and analyze the necessary information and finally present it to the class in a logical and structured way, in the form of a text, pictures, videos, diagrams or infographics.

At the beginning of the lesson the teacher sets the topic and tasks. The introduction to the topic of the lesson consisted of watching and discussing a video about the possibilities of spending money for different purposes. After the introduction to the topic of the lesson, the learners were 
asked to split into working groups and create a project. The idea was to plan a trip by working out their vacation program and making an economic plan for the funds distribution throughout the trip. After working in mini-groups to create projects, the learners presented and defended their project works in front of the class and received feedback from the classmates and the teacher. During the lesson, the learners interacted with each other in English, searched for the information on various Internet resources, independently chose the direction of their projects, prepared presentations, and defended them in a foreign language.

All the techniques used in the lesson were successful. The ESL teacher conducted the lesson in a question-and-answer form through interactive and play activities by using the PBL method. Overall, this experimental lesson had a practical and communicative focus. All the tasks proposed were completed; the learners were very active in the classroom, they were effectively working in a team and the general activity level in the lesson was both verbal and intellectual. The atmosphere of the PBL lesson was extremely dynamic because everyone was motivated to complete their tasks. The teacher was monitoring the inclusion of every pupil in the project work.

Based on the results of the experimental work in the ESL class, a special survey was conducted to evaluate the young learners' results under study. The survey was anonymous and contained the following questions:

1. Please, assess your involvement in the lesson from 0 to 5 points.

2. Please, assess the format of work in the lesson from 0 to 5 points.

3. Please, leave your our comment.

Fig. 7. Young learners' involvement in the English language lesson as a result of the survey

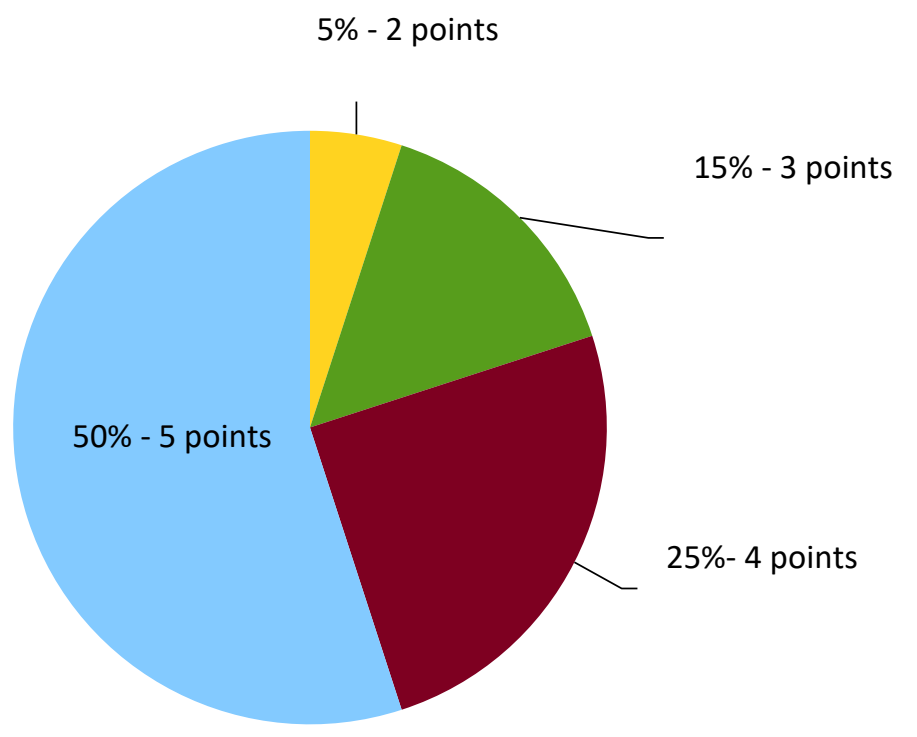


Fig. 8. Young learners' assessment of the work format in the English language lesson as a result of the survey

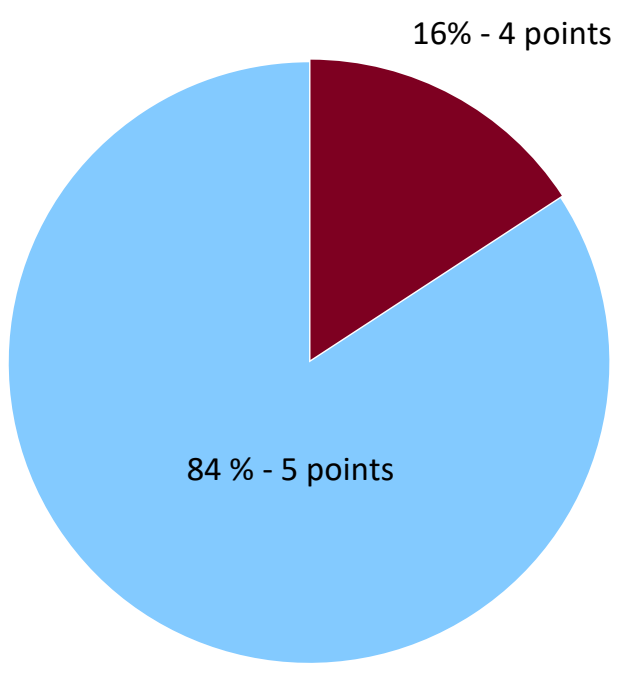

According to the learners' survey on introducing an ESL lesson with the help of the projectbased learning method, one can conclude that this method is relevant for working with children in a contemporary comprehensive school. Figures 7 and 8 above demonstrate young learners' satisfaction with their involvement in the English language classroom activities and the whole format of their work in the lesson. The results are positive ( $75 \%$ and $84 \%$ correspondingly). Therefore, it is important to notice schoolchildren's interest and motivation to participate in interactive and dynamic classes. At the end of the experimental ESL lesson the learners left their comments about their "desire to learn English better". They also mentioned that through teamwork, they "got to know each other more and will now communicate with each other more often."

Thus, the PBL method has a positive effect on the adolescents' motivational sphere, and is also a team-building link, shaping their emotions in the classroom. Finally, the results of the survey have demonstrated the successful implementation of the ESL lesson by means of the project methodology.

\section{DISCUSSION}

Project-based learning when used in foreign language classes (for example, when studying English) has become one of the most effective educational forms, organizing teaching and academic work in the classroom (Mudrik, 2001). PBL is a successful instrument to shape and develop young learners' personalities who can navigate in information nowadays and find the essence in its flow, synthesize and analyze the received information content, make decisions, think critically, work in a team, manage their quality time and many other soft skills important for any future professional of the XXIst century. Project-based learning method is aimed not only at improving speaking skills as well as updating all types of speech activity, but also developing a learner's personality itself, that is their emotional intelligence level, their interest towards self-knowledge and reflection (Guslyakova \& Guslyakova, 2019).

Overall, making project-based learning an essential component of the teacher's work should be a must in a present-day comprehensive school in foreign language classes as it can become one of the best methods to stimulate learners' motivation in studying a foreign language; to develop different kinds of brain memory and thinking, imagination, creativity and attention. 
Project-based learning becomes an effective method of teaching all types of speech activity and corresponds with the main principles of instruction according to the Federal State Educational Standard.

PBL gives teachers and educators important opportunities to follow the breakthrough educational trends in the world and shape their professional pedagogical skills according to the latest demands and challenges of the third millennium society.

\section{CONCLUSION AND RECOMMENDATIONS}

The findings of this experimental study dedicated to the project-based learning in English as a foreign language classes allowed identifying the following advantages of using the PBL method in a contemporary comprehensive school.

1. The PBL contributes to the development of young learners' communication skills.

2. It helps an ESL teacher carry out midpoint assessment of the grammatical structures and lexical units learned earlier.

3. The project-based learning allows the educator to effectively introduce schoolchildren to a foreign language communication environment, and thereby provoking the activity of learners' conversational speech.

4. Schoolchildren learn to analyze their own activities in the classroom, evaluate their language abilities as well as improve their reflection skills.

5. The PBL method triggers young learners' cognitive interest and motivation to master the English language; it also demonstrates the practical importance of using English as a foreign language on the example of group work within the framework of a certain topic of interest to pupils.

6. The method immerses schoolchildren in situational communication in a foreign language, which makes it possible to bring speaking in English much closer to the real language situation.

In the process of organizing project activities, we can highlight the following recommendations, based on the English as a foreign language classes supported by a project-based learning method in this experimental research:

1. A foreign language teacher should manage the limited amount of time of the lesson so that each learner could reveal their talents and express themselves, including their self-expression in a foreign language.

2. A foreign language teacher should support and guide learners at all stages of their project work in the classroom and pay a particular attention to the development of schoolchildren's PBL skills (e.g. individual and teamwork; researching and analyzing the required information, critical thinking, etc.).

3. Sometimes insufficient amount of a foreign language vocabulary makes young learners switch to their native language (for example, Russian) so as to interact and analyze the information given and prepare a project itself. In this case a teacher should do preliminary work with their learners to introduce the necessary vocabulary and communication clichés to minimize the usage of a native language during PBL work.

4.At the end of each project-based learning class it is essential for a foreign language teacher to get together with young learners and discuss as well as analyze the positives and negatives of the project-based lesson. Such an action will help to better plan each next PBL foreign language class and avoid as many unnecessary obstacles as it is possible.

In the end, it is necessary to mention that our working hypothesis related to high efficiency of PBL method which helps stimulate learners' potential and interest in foreign language acquisition has been completely proved. Overall, we suggest that project-based learning should be introduced on an ongoing basis in the contemporary school curriculum for teaching foreign languages. 
Authors' Contributions: Alla Guslyakova: conception and design, acquisition of data, analysis and interpretation of data, drafting the article, critical review of important intellectual content. Nina Guslyakova: conception and design, acquisition of data, analysis and interpretation of data, drafting the article, critical review of important intellectual content. Nailya Valeeva: conception and design, acquisition of data, analysis and interpretation of data, drafting the article, critical review of important intellectual content. Ludmila Veretennikova: conception and design, acquisition of data, analysis and interpretation of data, drafting the article, critical review of important intellectual content. All authors have read and approved the final version of the manuscript.

Ethics Approval: Not applicable.

Acknowledgments: Not applicable.

\section{REFERENCES}

Aplaeva, J. (2017). Project Method as an Innovative Technology for Teaching English. ICT for language learning, 10th edition, pp. 445 - 448. Retrieved from: https://conference.pixel-online.net/ICT4LL/files/ict4II/ed0010/FP/4206QIL2774-FP-ICT4LL10.pdf

Beckett, G.H. (2006). Project-based second and foreign language education: Past, present, and future. Greenwich, CT: Information Age Publishing.

Crisafidis, K. (2005). Experiential-communicative teaching. Implementing the project method in school. Athens: Gutenberg.

Erokhina, P.A. (2018). Metod proyektov - odin iz sovremennykh metodov obucheniya v usloviyakh realizatsii FGOS [The project method is one of the modern teaching methods in the context of the implementation of the Federal State Educational Standard]. All-Russian Scientific and Practical conference. TOP-50 standards as a vector of professional development education (pp. 246-251). Kurgan.

Fragoulis, I. (2009). Project-Based Learning in the Teaching of English as A Foreign Language in Greek Primary Schools: From Theory to Practice. English Language Teaching, 2(3), 113 - 119.

Frey, K. (1986). The project method. Thessaloniki, Kyriakidis.

Fried-Booth, D. L. (2002). Project work. Second edition. Oxford: Oxford University Press.

Guslyakova, A.V. \& Guslyakova, N.I. (2019). Vliyaniye refleksii na professional'noye stanovleniye molodogo spetsialista [The influence of reflection on the professional development of a young specialist]. Modern problems of science and education, 4, 109.

Haines, S. (1989). Projects for the EFL Classroom: Resource Material for Teachers. Nelson.

Kagarov, E.G. (1926). Metod proyektov v trudovoy shkole [The method of projects in a labor school]. Moscow: Brockhaus Efrop.

Kalvu, A. (2015). Project-based learning assessment methods comparison in undergraduate EFL classes. International Journal of Social Sciences \& Educational Studies, 1(4), 47-56.

Krupskaya, N.K. (1962). Pedagogicheskiye sochineniya [Pedagogical essays]. Moscow.

Lam, S., Cheng, R.W., Choy, H.C. (2010). School support and teacher motivation to implement project-based learning. Learning and instruction, 20(6), 487-497. https://doi.org/10.1016/j.learninstruc.2009.07.003

Levine, G.S. (2004). Global simulation: a student-centered, task-based format for intermediate foreign language courses. Foreign Language Annals, 37(1), 26-36. https://doi.org/10.1111/j.1944-9720.2004.tb02170.x

Mudrik, A.V. (2001). Obshcheniye v protsesse vospitaniya [Communication in the process of education]. Moscow: Pedagogical Society of Russia.

Muniandy, B. (2000). An investigation of the use of constructivism and technology in project-based learning. PhD Thesis. University of Oregon.

Nguyen, T.V. (2011). Project-based learning in teaching English as a foreign language. VNU Journal of Science, Foreign Languages, 27(2), 140-146.

Pestalozzi, I.G. (1965) Izbrannyye pedagogicheskiye proizvedeniya v trekh tomakh, Tom 3. 1805-1827. [Selected pedagogical works in three volumes, volume 3. 1805-1827]. Moscow: Publishing House of the Academy of Pedagogical Sciences of the RSFSR. 
Poonpon, K. (2011). Enhancing English skills through project-based learning. The English Teacher, XL, 1-10.

Rousseau, J.J. (1981). Pedagogicheskaya biblioteka. Pedagogicheskiye sochineniya [Pedagogical library. Pedagogical works]. volume 1, by G. N. Dzhibiladze, Ed., Academy of Pedagogical Sciences. Moscow: Pedagogika.

Sadeghi, H., Biniaz, M. \& Soleimani, H. (2016). The impact of project-based language learning on Iranian EFL learners' comparison/contrast paragraph writing skills. International Journal of Asian Social Science, 6(9), 510-524.

Shatskiy, S.T. (1965). Pedagogicheskiye sochineniya v chetyrokh tomakh [Pedagogical works in four volumes]. I.A. Kairova, L.N. Skatkina, M.N. Scouting \& V.N. Shatskaya (Eds.). Moscow: Education.

Simpson, J. (2011). Integrating project-based learning in an English language tourism classroom in a Thai university institution. Doctoral Thesis, Australian Catholic University. https://doi.org/10.4226/66/5a961e4ec686b

Solomon, G. (2003). Project-based learning: A primer. Technology \& Learning, 23, 20-27.

Srikrai, P.S. (2008). Project-based learning in an EFL classroom. Journal of Humanities and Social Sciences. Khon Kean University, 25, $85-111$.

Stoller, L. S. (1997). Project work: A means to promote language content. Forum, 35(4), 2-18.

Thuan, P.D. (2018). Project-based learning: from theory to EFL classroom practice. Proceedings of the 6th International OpenTESOL Conference. Ho Chi Minh City Publishing House of Economics, 327 - 339.

Veretennikova, L.K. (2019). Strategiya i kontseptsiya formirovaniya tvorcheskogo potentsiala i kreativnosti obuchayushchikhsya $v$ innovatsionnoy srede [Strategy and concept of formation of students' creative potential and creativity in an innovative environment]. Moscow: Moscow State Pedagogical University.

Willie, S. L. (2001). Project based learning with multimedia. Redwood, CA: San Mateo County Office of Education.

Wolk, S. (1994). Project-Based Learning: Pursuits with a Purpose. Educational Leadership, 52(3), 42-45.

Received: 31 June 2021 | Accepted: 20 September2021 | Published: 18 November 2021

This is an Open Access article distributed under the terms of the Creative Commons Attribution License, which permits unrestricted use, distribution, and reproduction in any medium, provided the original work is properly cited. 